\title{
Increasing radial and latewood growth rates of Larix cajanderi Mayr. and Pinus sylvestris L. in the continuous permafrost zone in Central Yakutia (Russia)
}

\author{
Alberto Arzac ${ }^{1}$ (D) Margarita Popkova ${ }^{1} \cdot$ Altynai Anarbekova $^{1} \cdot$ José Miguel Olano $^{2} \cdot$ Emilia Gutiérrez $^{3}$. \\ Anatoly Nikolaev ${ }^{4,5} \cdot$ Vladimir Shishov ${ }^{1,6}$
}

Received: 15 April 2019 / Accepted: 27 August 2019 / Published online: 17 October 2019

(C) INRA and Springer-Verlag France SAS, part of Springer Nature 2019

\begin{abstract}
- Key message Annual radial growth and latewood formation increase during the period 1966-2015 in Larix cajanderi Mayr. and Pinus sylvestris L. along a latitudinal gradient on Siberian permafrost. Warmer temperatures and precipitation at the onset of the growth season favor growth in both species.

- Context A vast area of Siberian boreal forest is covered by continuous permafrost, where tree radial growth is strongly limited by low temperatures. Understanding how climate controls Siberian conifer growth is critical in order to predict their response to ongoing climate change.

- Aims To explore variations in the radial growth and earlywood/latewood formation of Pinus sylvestris L. and Larix cajanderi Mayr. trees along a climate gradient within the continuous permafrost zone in Central Yakutia (Russia), a region experiencing accelerated warming.

- Methods We evaluated spatiotemporal differences in tree-ring and latewood width among sites by using generalized additive mixed models. Pearson's correlations were used to analyze the effect of local climate (temperature, precipitation) and drought (SPEI) on the formation of earlywood and latewood.

- Results Both conifers showed increased radial growth in recent decades. Radial growth was controlled by temperature and precipitation in both species along the gradient, with earlier precipitation events being critical for the formation of wide rings.

- Conclusion Although temperature is considered as the main limiting factor triggering tree growth in the continuous permafrost zone, our results showed that water availability also plays a key role in radial tree growth even in the coldest sites.
\end{abstract}

Keywords Central Yakutia $\cdot$ Climate $\cdot$ General additive mixed models $\cdot$ Pointer years $\cdot$ SPEI $\cdot$ Tree growth

This article is part of the topical collection on Wood formation and tree adaptation to climate

Handling Editor: Cyrille B. Rathgeber

Contributions of the co-authors A. Arzac contributed to the project design, analyzed the data, and wrote the manuscript. M. Popkova, A. Anarbekova, and A. Arzac were responsible for RW, EW, and LW measurements and chronologies. JM Olano and E. Gutiérrez contributed to the interpretation of the results and helped in writing the manuscript. A. Nikolaev and V. Shishov were responsible for the field works. V. Shishov also contributed to the project design and funding acquisition. All the authors reviewed the paper.

Alberto Arzac aarzac@gmail.com

1 Siberian Federal University, 79 Svobodny pr., Krasnoyarsk, Russia 660041

2 iuFOR-EiFAB, Universidad de Valladolid, 42004 Soria, Spain
3 Department of Evolutionary Biology, Ecology and Environmental Sciences, Faculty of Biology, University of Barcelona, Barcelona, Spain

4 North-Eastern Federal University, Yakutsk, Russia

5 P. I. Melnikov Institute of Permafrost, Yakutsk, Russia

6 UMR 588 BIOFORA, Centre INRA Val de Loire, Nouzilly, France 


\section{Introduction}

Boreal forests play a leading role in regional and global climate systems, affecting the global carbon balance and water cycle (Melnikov and Drozdov 2006; Falkowski et al. 2010; Schlesinger and Jasechko 2014). However, up to $80 \%$ of these forests occur in the permafrost zone (Helbig et al. 2016) and are thus highly sensitive to changes in climate (Gartenr 1995; Sperry et al. 2006). A vast area of Siberian boreal forest in high latitudes is covered by continuous permafrost (Duchkov 2006), where the active soil layer remains frozen for most of the year (Lopez et al. 2010; Nikolaev et al. 2011) and tree growth is strongly limited by spring-summer temperatures (Briffa et al. 1998, 2008; Vaganov et al. 1999; Hellmann et al. 2016).

The accelerated warming observed in northeastern Siberia during recent decades (Gorokhov and Fedorov 2018) has induced an increase in the active soil layer depth, facilitating tree growth (Bosikov 1998; Fedorov and Konstantinov 2003). The impact of warming (IPCC 2014) might, therefore, be positive for tree growth in this environment due to the lengthening of the growing season (Nikolaev et al. 2011). However, the increase of temperature over a certain threshold might also lead to an excess of soil moisture, triggering the degradation of permafrost and leading to forest fragmentation and forest loss (Lopez et al. 2008; Baltzer et al. 2014; Jorgenson and Osterkamp 2005; Carpino et al. 2018), potentially compromising the boreal forest role in global carbon and water cycles. Therefore, understanding tree responses to a wide range of environmental conditions within the continuous permafrost zone might provide a clearer insight into the factors controlling tree performance and ultimately forest functioning.

Tracheid cells make up more than $90 \%$ of xylem in conifers (Vaganov et al. 2006), combining hydraulic (earlywood) and structural (latewood) functions (Tyree et al. 2002). Since tracheid formation, anatomy, and functioning are strongly related to climate conditions (Antonova and Stasova 1993, 1997; Zweifel et al. 2006; Olano et al. 2012; Babushkina et al. 2018), they encode different environmental information (Vaganov 1990; Fonti et al. 2010; Arzac et al. 2018a, b; Popkova et al. 2018). Thus, an independent analysis of the climatic factors controlling the formation of different tree-ring sectors (i.e., earlywood and latewood) is critical to determine the extent to which climate control on tree growth varies along the growing season.

The intra-seasonal change in xylem morphology (from earlywood to latewood cells) might be driven by the need for structural reinforcement by latewood (e.g., Gartenr 1995; Sperry et al. 2006), photoperiod (e.g., Gyllenstrand et al. 2007), or changes in water availability (e.g., Antonova and Stasova 1997; Olano et al. 2014) throughout the growing season. Since earlywood and latewood cells are related towards different functions (Björklund et al. 2017), the ratio between the two treering sectors plays a critical role in tree water-carbon interactions (Hacke et al. 2001; Domec and Gartner 2002). In the permafrost zone, temperature determines growing season length due to the timing of permafrost thawing (Lopez et al. 2010; Nikolaev et al. 2011), controlling the cell production and radial cell expansion (Vaganov et al. 1999), and, also, in the secondary wall thickening and the formation of latewood cells, as evidenced by the high correlations between maximum latewood density and summer temperature in the permafrost area (Briffa et al. 1998; Vaganov et al. 1999).

In this work, we analyzed the climatic factors controlling the radial growth (tree-ring width) and earlywood/ latewood formation of two dominant conifers of Siberian boreal forests, the deciduous and frost-resistant Larix cajanderi Mayr and the evergreen Pinus sylvestris L. along a southwest-northeast gradient on the continuous permafrost zone in Central Yakutia. P. sylvestris grows mostly on dry sands or sandy loams, with high permafrost thawing (Nikolaev 2003; Nikolaev et al. 2011), whereas L. cajanderi grows on moderately moist loams (Nikolaev et al. 2009), and is the dominant conifer in the permafrost zone (Abaimov 2010). Also, the two conifers develop shallow root systems that enable them to thrive despite the occurrence of permafrost in the deeper soil horizons (Nikolaev et al. 2009, 2011).

Central Yakutia is experiencing an accelerated increase in temperatures in recent years (Gorokhov and Fedorov 2018), which may have extended the tree-growing season. Along an altitudinal/latitudinal gradient in Central Yakutia, we explored (a) whether radial growth has increased in response to warmer conditions. Additionally, we evaluated the relative roles of temperature and water availability in the two conifers. We hypothesized that (b) temperature and soil moisture availability would be critical for the formation of earlywood, while temperature would be the main factor triggering the formation of latewood along the gradient. Finally, we hypothesized that (c) higher growth rates associated with wide rings would be linked with an earlier timing of precipitation, expanding the period of soil moisture availability.

\section{Materials and methods}

\subsection{Study area and sampling design}

We selected four sampling sites along a $1500-\mathrm{km}$ southwest-northeast climatic gradient of increasing 


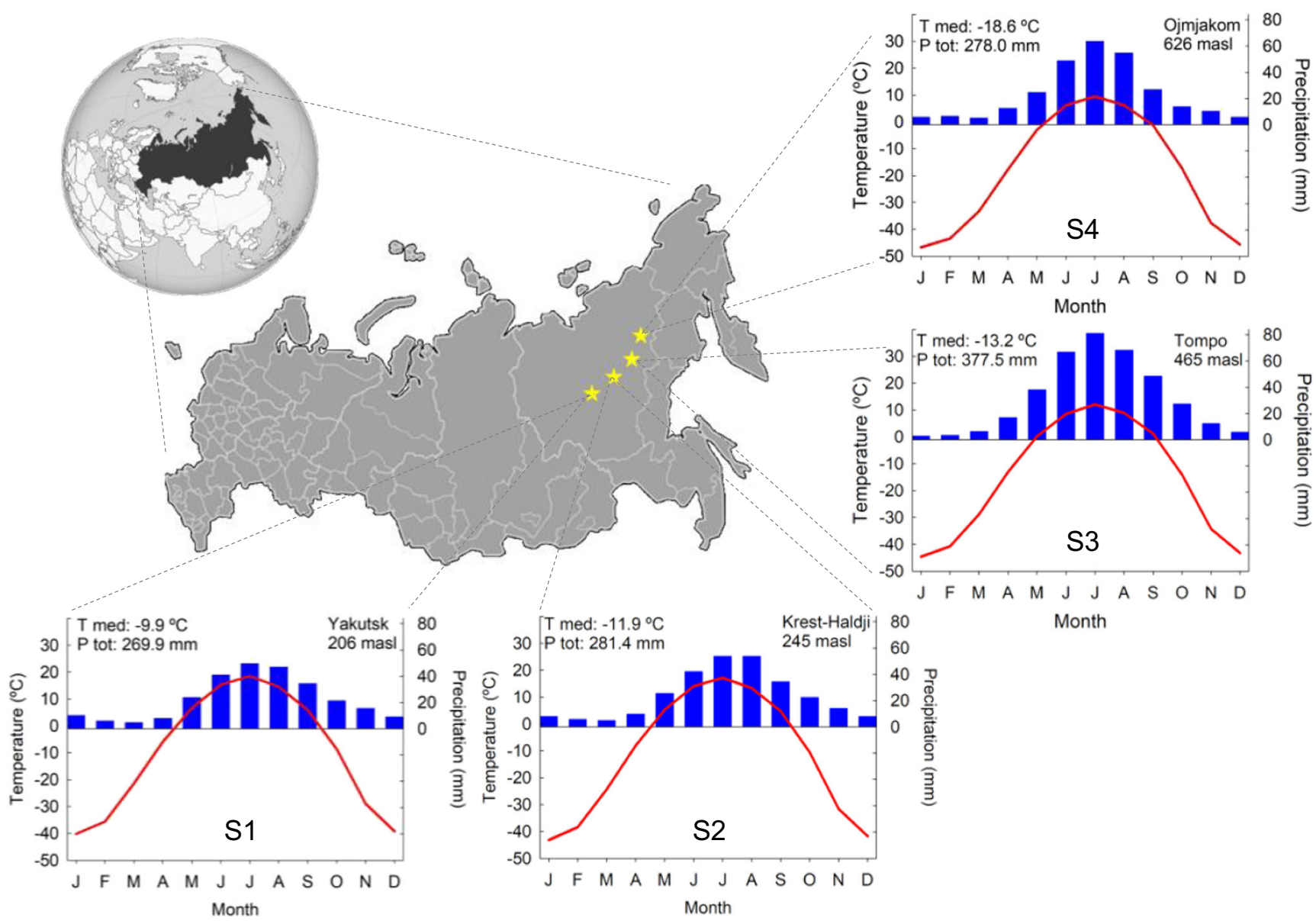

Fig. 1 Study area and comparison of mean yearly temperature and total yearly precipitation among sampling sites. The meteorological data covers the common period $1966-2015$ and was from $0.5^{\circ}$-resolution CRU grids

altitude within the continuous permafrost zone in Central Yakutia, from Yakutsk to Oymyakon (northeastern Siberia, Russia; Fig. 1). The region is characterized by extreme cold and dry continental climate (with an annual thermal amplitude of $60^{\circ} \mathrm{C}$ ). The first site (S1), the most southwestern, is located at $206 \mathrm{~m}$ asl near the locality of Yakutsk. The second site (S2) is located at $245 \mathrm{~m}$ asl close to the locality of Krest-Khaldzhay. The third site (S3) is located at $465 \mathrm{~m}$ asl near the locality of Tompo. Finally, the fourth site (S4), the most northeastern, is located at $626 \mathrm{~m}$ asl close to the locality of Oymyakon. The mean annual temperature along the gradient ranged from -9.9 to $-18.6{ }^{\circ} \mathrm{C}$ and the total annual precipitation from 269 to $377 \mathrm{~mm}$, with $\mathrm{S} 3$ being the wettest site (see Table 1 for further details). Climate data was obtained from a high-resolution $\left(0.5^{\circ}\right.$ grids $)$ CRU data set for a 50-year period (1966-2015), available at https://crudata. uea.ac.uk/cru/data/hrg/cru ts 3.23/ge/.

At each site (except in S4), we sampled mono-specific forest stands of $L$. cajanderi and $P$. sylvestris during summer 2015. Forest stands at each site were around 10$20 \mathrm{~km}$ apart. Larch trees were sampled at all the sites, whereas pine trees were sampled in all except the coolest S4. A total of 125 dominant or codominant trees were sampled (74 larches and 51 pines; Table 1), and two cores

Table 1 Characterization of the sampling sites. Meteorological data was obtained by $0.5^{\circ}$-resolution CRU grids for the common period 1966-2015. Lc, Larix cajanderi; Ps, Pinus sylvestris

\begin{tabular}{|c|c|c|c|c|c|}
\hline & & $\mathrm{S} 1$ & $\mathrm{~S} 2$ & $\mathrm{~S} 3$ & S4 \\
\hline \multirow[t]{2}{*}{ Trees } & $L c$ & 21 & 19 & 14 & 20 \\
\hline & $P S$ & 21 & 15 & 15 & - \\
\hline Age (mean + SD) & $\begin{array}{l}L c \\
P s\end{array}$ & $\begin{array}{l}112 \pm 33 \\
128 \pm 34\end{array}$ & $\begin{array}{l}91 \pm 22 \\
84 \pm 8\end{array}$ & $\begin{array}{l}148 \pm 29 \\
90 \pm 41\end{array}$ & $\begin{array}{l}75 \pm 16 \\
-\end{array}$ \\
\hline Latitude & & $62^{\circ} 9^{\prime} \mathrm{N}$ & $62^{\circ} 19^{\prime} \mathrm{N}$ & $63^{\circ} 21^{\prime} \mathrm{N}$ & $\begin{array}{c}64^{\circ} 25^{\prime} \\
\mathrm{N}\end{array}$ \\
\hline Longitude & & $\begin{array}{c}130^{\circ} 31^{\prime} \\
\mathrm{E}\end{array}$ & $\begin{array}{c}133^{\circ} 31^{\prime} \\
\mathrm{E}\end{array}$ & $\begin{array}{c}137^{\circ} 58^{\prime} \\
\mathrm{E}\end{array}$ & $144^{\circ} 3^{\prime} \mathrm{E}$ \\
\hline Altitude (m asl) & & 206 & 245 & 465 & 626 \\
\hline Annual mean $\mathrm{T}\left({ }^{\circ} \mathrm{C}\right.$ & & -9.9 & -11.9 & -13.2 & -18.6 \\
\hline Mean MJJA T $\left({ }^{\circ} \mathrm{C}\right)$ & & 13.7 & 12.4 & 7.4 & 5.2 \\
\hline Total annual P (mn & & 269 & 281 & 377 & 278 \\
\hline MJJA P (mm) & & 161 & 174 & 254 & 191 \\
\hline
\end{tabular}


per tree were taken at breast height with a 5-mm diameter increment borer. Cores were air-dried and polished with successively finer grades of sandpaper until the xylem structure was visible under magnification.

\subsection{Tree-ring measurements and chronologies}

After visual cross-dating, tree-ring width (RW), earlywood width (EW), and latewood width (LW) were measured to the nearest $0.01 \mathrm{~mm}$ by using a LINTAB- 5 sliding stage micrometer interfaced with the software TSAP Win (RINNTECH, Heidelberg, Germany) in a total of 12,156 annual rings. Cross-dating accuracy was checked using the software COFECHA (Grissino-Mayer 2001), and each raw series was standardized using the software ARSTAN (Cook and Holmes 1996). Spline functions were fitted to the raw series to a spline function with a $50 \%$ frequency cutoff at 32 years, which was flexible enough to reduce the non-climatic variance preserving high-frequency climatic information (Cook and Peters 1981). In addition, dendrochronological statistical measures (e.g., mean sensitivity and expressed population signal) were obtained from ARSTAN. Due to the high correlation between EW and LW chronologies (mean correlations $r=0.7$ for larch and $r=0.5$ for pine), a linear regression was used to remove the dependence of LW on EW (Babst et al. 2016), obtaining an adjusted latewood index $\left(\mathrm{LW}_{\mathrm{adj}}\right)$ (Meko and Baisan 2001) non-correlated with EW chronology (Stahle et al. 2009).

\subsection{Pointer years}

We analyzed the climatic factors driving the formation of wide and narrow tree-rings (pointer years) for each species and site during a 50-year period (1966-2015). The definition of pointer years was based on the deviation from mean values of the tree-ring width index chronologies. Thus, years with RW index $1 \mathrm{SD}$ above the mean RW chronology were considered as wide rings, whereas years with RW index 1 SD below the mean RW chronology were considered as narrow rings (Shi et al. 2008; Tychkov et al. 2019). Once pointer years were defined, monthly precipitation and temperature were averaged for pointer years to compare the environmental conditions triggering the occurrence of wide and narrow rings.

\subsection{Statistical analysis}

We performed generalized additive mixed models (GAMM, Zuur et al. 2009) to assess inter-site differences in whole ring and latewood width (absolute values) as well as temporal trends in tree growth. We evaluated trends in growth rate using "year" as a linear factor; if growth has increased/reduced along the studied period, "year" would have a positive/negative effect and no significant effect of "year" would mean no temporal trend. Decrease in growth with tree age may obscure temporal growth trend effect. Therefore, to remove this confounding factor, we modeled age-related radial growth changes with a non-linear function using a smoother. Additionally, we considered measurements nested within tree and temporally autocorrelated. Thus, each tree-ring trait was evaluated as a function of the site (nominal variable), year (linear variable representing the temporal trend), tree age (modeled using a smoother), and nested within tree with a temporal autocorrelation. Analyses were performed in R, version 3.3.1 (R Development Core Team 2016) with the "nmle" package.

A climate analysis was performed to evaluate the trend in the mean annual temperature and the total annual precipitation for the 1966-2015 period in all the sites. Additionally, we also evaluated seasonal trends in climate. We used Pearson's correlations to explore the relationship between residual RW, EW, and $\mathrm{LW}_{\mathrm{adj}}$ chronologies and monthly climatic factors for the common period (19662015) at each site, for a time window from August of the previous year to September of the growth year (July in the case of EW). Climate data series were standardized following the same procedure as for the tree-ring chronologies.

Finally, we used the standardized precipitationevapotranspiration index (SPEI, Vicente-Serrano et al. 2010), available at http://spei.csic.es/database.html, to evaluate the differential effect of soil water balance on the analyzed chronologies at different temporal scales in which the water deficit is accumulated. We calculated Pearson's correlation between RW, EW, and $\mathrm{LW}_{\mathrm{adj}}$ chronologies and SPEI from September prior to the growth year to the current (growth year) August over different time scales (1-18 months), which are also available at the SPEI database.

\section{Results}

\subsection{Climate trends}

During the period 1966-2015, mean annual temperature has increased at a rate between $0.47^{\circ} \mathrm{C} /$ decade $\left(R^{2}=0.45\right.$; $P<0.001)$ at site $\mathrm{S} 4$ to $0.65{ }^{\circ} \mathrm{C} /$ decade $\left(R^{2}=0.55\right.$; $P<0.001$ ) at site $\mathrm{S} 1$ (Fig. 2). The tree growth season, defined by daily mean temperature above $5{ }^{\circ} \mathrm{C}$, extended from May to September in S1 and S2 and from June to August in S3 and S4. Interestingly, the lower southwestern sites (S1 and S2) have experienced a greater increase in summer and winter temperatures, while the higher 
Fig. 2 Mean annual temperature trends for the four sampling sites during the common period 1966 2015. Mean annual temperature trends (a). Variation in temperature by seasons $(\mathbf{b})$

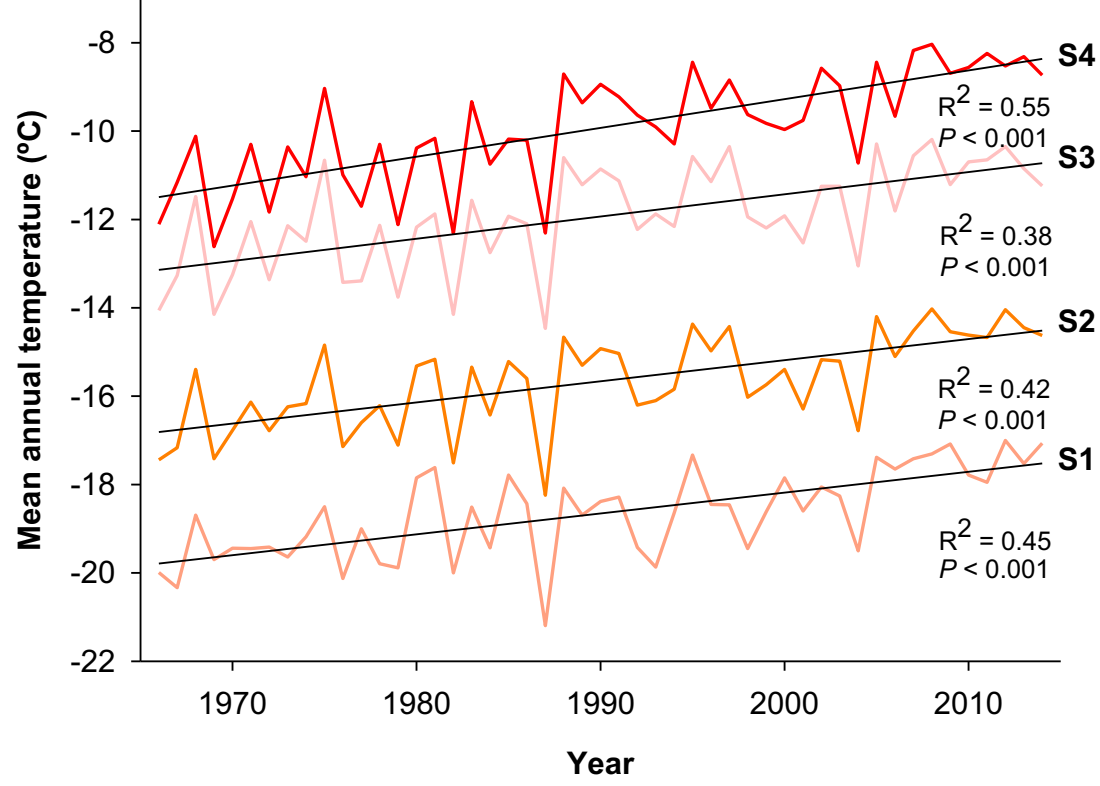

northeastern sites (S3 and S4) experienced the highest rates of temperature increase in spring and autumn (data not shown). No significant trend in precipitation was detected in any of the sites for the study period.

\subsection{Variation of radial growth and latewood width}

Tree age ranged from 75 to 148 years $(103 \pm 36$; mean \pm SD) for larch to $84-128$ years $(105 \pm 37)$ for pine. RW was $0.57-1.11 \mathrm{~mm}(0.78 \pm 0.23$; mean $\pm \mathrm{SD})$ in larch and $0.56-1.29 \mathrm{~mm}(0.94 \pm 0.37)$ in pine (see Annex Table 4 for further details). Ring width chronologies showed values of mean correlation between trees $\left(r_{\mathrm{bt}}\right)$ from 0.32 to 0.43 for larch and 0.18 to 0.40 for pine, while RW residual chronologies mean sensitivity $\left(m_{\mathrm{sx}}\right)$ ranged from 0.17 to 0.21 for larch and 0.09 to 0.16 for pine. Expressed population signal (EPS) was over 0.85 for all the sites except pines in S3 (Annex Table 4), suggesting adequate replication and a high common signal in each locality except for pine chronology in S3. Within-species RW correlations showed non-significant values for larch sites and moderate but significant values for pine sites $(r=0.34$ $0.48 ; P<0.001$, Annex Table 5). Between-species correlation was only significant in the lowest site $(\mathrm{S} 1, r=0.56$; $P<0.001$, Annex Table 6).

GAMM produced a satisfactory model for tree age in both species and parameters, suggesting a negative effect of tree age on radial and latewood growth (Table 2; Annex Fig. 6). At the same time, "year" (as linear variable representing the temporal trend) had a positive effect in all the models indicating that RW and LW growth rates had increased throughout the life of sampled trees for both species. RW had increased at a rate of $1.7 \mu \mathrm{m} /$ decade in pine and $3.5 \mu \mathrm{m} /$ decade in larch, whereas LW increased at a rate of 0.4 and $1.2 \mu \mathrm{m} /$ decade in pine and larch, respectively (Table 2). Pairwise comparisons also indicated growth rate differences between sites. Pine RW showed the lowest growth rate in S1, being marginally higher at $\mathrm{S} 3$ than S2. Pine latewood growth rate was highest at S3, with no differences between S1 and S2. Larch RW growth was higher in S3 than $\mathrm{S} 1$ and $\mathrm{S} 2$, with $\mathrm{S} 4$ being intermediate (marginally lower than S3 and higher than S1, S2). Finally, larch LW growth was also higher in S3, but there was no difference between the other sites (Table 2; Fig. 3).

\subsection{Climate-growth response}

Pearson's correlations between standardized climatic variables and tree-ring trait chronologies were significant in both species for the common period 1966-2015. Since RW and EW were highly correlated in all the cases $(r>$ $0.86 ; P<0.001)$, climate-growth relationships are only shown for EW and $\mathrm{LW}_{\text {adj }}$ (Figs. 4 and 5). The effect of temperature on larch EW was site-dependent, with a positive response to temperature in previous November in S2 and March and July of the current year in S3, whereas a negative effect of May temperature appeared in S4. In contrast, temperatures from March to May had a positive effect in $\mathrm{LW}_{\text {adj }}$ in all the sites except S1 (March), while a negative effect was seen for temperature in previous year October and current year June in S4, July in S1, and August in S3. The effect of temperature on pine growth was clearer (Fig. 4). April temperature positively affected 
Table 2 Estimated parameters of the generalized additive model for radial growth and latewood in Larix cajanderi and Pinus sylvestris

\begin{tabular}{|c|c|c|c|c|c|c|}
\hline & & & Estimate & SE & $t$ & $P$ \\
\hline \multirow[t]{15}{*}{ Ring width } & Larch & Intercept & -628.222 & 170.609 & -3.682 & $<0.001$ \\
\hline & & Year & 0.349 & 0.087 & 4.011 & $<0.001$ \\
\hline & & $\mathrm{S} 1$ & 0 & & & $\mathrm{a}$ \\
\hline & & $\mathrm{S} 2$ & 1.203 & 5.519 & 0.218 & a \\
\hline & & $\mathrm{S} 3$ & 30.214 & 6.214 & 4.862 & $\mathrm{~b}$ \\
\hline & & $\mathrm{S} 4$ & 10.887 & 6.132 & 1.775 & $a b$ \\
\hline & & Age & edf & & $F$ & \\
\hline & & & 1 & & 78.07 & $<0.001$ \\
\hline & Pine & Intercept & -287.121 & 134.246 & -2.139 & 0.032 \\
\hline & & Year & 0.174 & 0.069 & 2.528 & 0.011 \\
\hline & & $\mathrm{S} 1$ & 0 & & & a \\
\hline & & $\mathrm{S} 2$ & 21.623 & 5.834 & 3.706 & $a b$ \\
\hline & & $\mathrm{S} 3$ & 32.121 & 5.749 & 5.587 & $\mathrm{~b}$ \\
\hline & & Age & edf & & $F$ & \\
\hline & & & 5.325 & & 17.06 & $<0.001$ \\
\hline \multirow[t]{15}{*}{ Latewood } & Larch & Intercept & -212.486 & 77.530 & -2.741 & $<0.01$ \\
\hline & & Year & 0.121 & 0.039 & 3.080 & $<0.01$ \\
\hline & & $\mathrm{S} 1$ & 0 & & & $\mathrm{a}$ \\
\hline & & $\mathrm{S} 2$ & -2.655 & 2.512 & -1.057 & $\mathrm{a}$ \\
\hline & & $\mathrm{S} 3$ & 10.212 & 2.813 & 3.630 & b \\
\hline & & S4 & -2.996 & 2.789 & -1.074 & $\mathrm{a}$ \\
\hline & & Age & edf & & $F$ & \\
\hline & & & 5.232 & & 15.95 & $<0.001$ \\
\hline & Pine & Intercept & -72.062 & 30.709 & -2.374 & 0.018 \\
\hline & & Year & 0.043 & 0.015 & 2.768 & $<0.01$ \\
\hline & & $\mathrm{S} 1$ & 0 & & & $\mathrm{a}$ \\
\hline & & $\mathrm{S} 2$ & 1.769 & 1.411 & 1.253 & $\mathrm{a}$ \\
\hline & & $\mathrm{S} 3$ & 6.318 & 1.361 & 4.640 & $\mathrm{~b}$ \\
\hline & & Age & edf & & $F$ & \\
\hline & & & 1 & & 52.47 & $<0.001$ \\
\hline
\end{tabular}

EW, with an increase of the climatic signal from the warmer to the coldest sites. However, a negative effect was observed in previous December and current January temperatures in S2 and S3, respectively. The positive effect of temperature on $\mathrm{LW}_{\mathrm{adj}}$ extended for two months (April and May) in all cases except S3, where temperature did not show a significant signal (Fig. 5).

Precipitation also showed a tight correlation with the two tree-ring sectors, although patterns were less clear in larch than in pine. EW was favored by June precipitation in the S1, S3, and S4 sites, February precipitation in S2 (but with a negative effect in S3), and April precipitation in S1. May precipitation also negatively affected EW in S2. Previous September precipitation was positively correlated with $\mathrm{LW}_{\text {adj }}$ in $\mathrm{S} 1$ and S3. March, June, and July precipitation were correlated with higher $\mathrm{LW}_{\text {adj }}$ values in S2, S3, and S4, respectively. Previous December (S3), March (S1), and April (S2) precipitation showed a negative effect on $\mathrm{LW}_{\mathrm{adj}}$. In contrast, the effect of precipitation was clearer in pine, with May precipitation favoring growth in $\mathrm{S} 2$ and $\mathrm{S} 3$, and June precipitation favoring growth in S1. LW adj responded to June (S1), July (S2), and August (S3) precipitation (Figs. 4 and 5).

In agreement with the significant impact of precipitation on residual chronologies, SPEI was significantly correlated in both species (Table 3). Larch EW residual chronologies showed moderate correlations with SPEI $(r=$ $0.39-0.53 ; P<0.01)$, with maximum intensity occurring in June in all sites except S2 (February), with a temporal scale ranging from 1 month in S2 to 12 months in S4. Pine EW residual chronologies were correlated with SPEI $(r=0.31-0.38 ; P<0.05)$ with maximum signals occurring earlier than in larch (May) in all but S1 (June) with a temporal scale from 8 months in S3 to 15 months in S1 (Table 3 ). In both species, the strongest signals were found in the drier and warmer site $\mathrm{S} 1$. $\mathrm{LW}_{\mathrm{adj}}$ larch chronologies also showed significant correlations with SPEI $(r=0.33-0.54 ; P<0.01)$, with maximum signals occurring from March in S2 to July in S3 (Table 3). The highest signal intensity was found in the driest site S1 in June. Temporal scales ranged from 1 month in $\mathrm{S} 1$ to 11 months in S3. In Scots pine, correlations between SPEI and $\mathrm{LW}_{\text {adj }}$ chronologies were lower but still significant in all sites except S3 $(r=0.33-0.38 ; P<0.01)$. The timing of the signal was earlier in S1 (January) than in S2 (July), with shorter temporal scales (1 to 2 months) than in larch sites.

\subsection{Climate effect on pointer year occurrence}

In each site, seven to nine years met the requirements to be considered pointer years (i.e., 1 SD above or below mean RW index chronologies), revealing differences between sites and species (see Annex Fig. 7). Although some pointer years were shared between sites, we also found unique pointer years (both narrow and wide rings) in each of the sites, highlighting local differences in the environmental conditions. The effect of precipitation triggering the formation of narrow and wide rings (Annex Fig. 8) showed a common pattern between sites and species (except in Larch S2), with wider rings occurring in years with higher precipitation events in the late spring and early summer (May-June), while narrow rings occurred in years with lower spring precipitation. Higher precipitation events that occurred later in the growing season (July-August) seem not to have affected the formation of wider rings, as shown by pine in sites S2 and S3. 
Fig. 3 Descriptive diagram of the main results from generalized additive mixed model, showing the components of the model and its effects on ring width (RW) and latewood width (LW) on Pinus sylvestris and Larix cajanderi

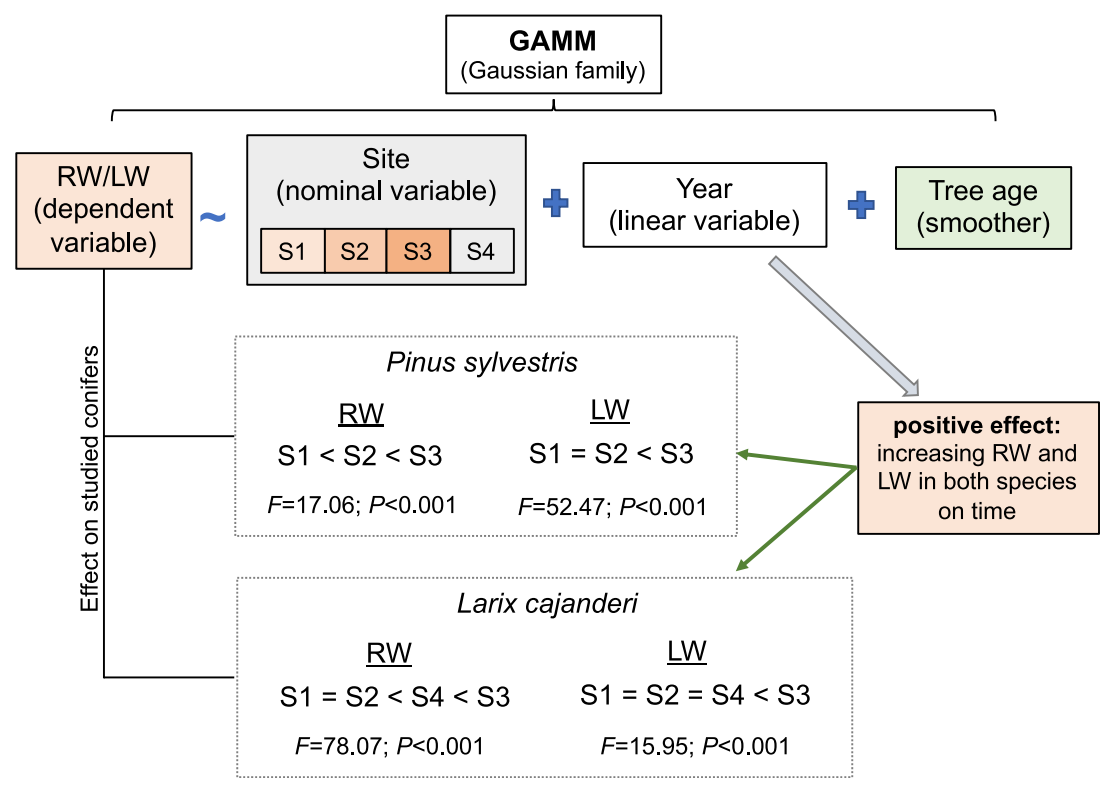

\section{Discussion}

Temperature and radial growth of $L$. cajanderi and P. sylvestris have increased from 1966 to 2015 along the studied gradient in Central Yakutia (northeastern Siberia). Spring-summer temperatures were critical for tree radial growth, although radial growth was also affected by water availability, since EW and $\mathrm{LW}_{\text {adj }}$ were correlated with precipitation. In addition, the occurrence of wide rings was related to an earlier occurrence of precipitation during the pointer years.

Tree growth is strongly limited by low temperatures in the Yakutia territory (Tchebakova et al. 2006) due to the supercooling of the root area during the winter (Sugimoto et al. 2003; Nikolaev et al. 2009, 2011), which can extend to May and June. The onset of cambial activity requires a minimum temperature threshold (Rossi et al. 2008, 2013), which in the continuous permafrost zone is related to
Fig. 4 Correlations (Pearson's coefficient) between earlywood (EW) and latewood adjusted $\left(\mathrm{LW}_{\text {adj }}\right)$ chronologies of Larix cajanderi with total precipitation and minimum temperature for the period 1966-2015. Correlations were calculated from August of the previous year (uppercase letters) to September of the current growth year (lowercase letters). Dashed lines indicated $P<0.05$, and dotted lines indicate $P<0.01$. Bar colors indicate the four sampled sites

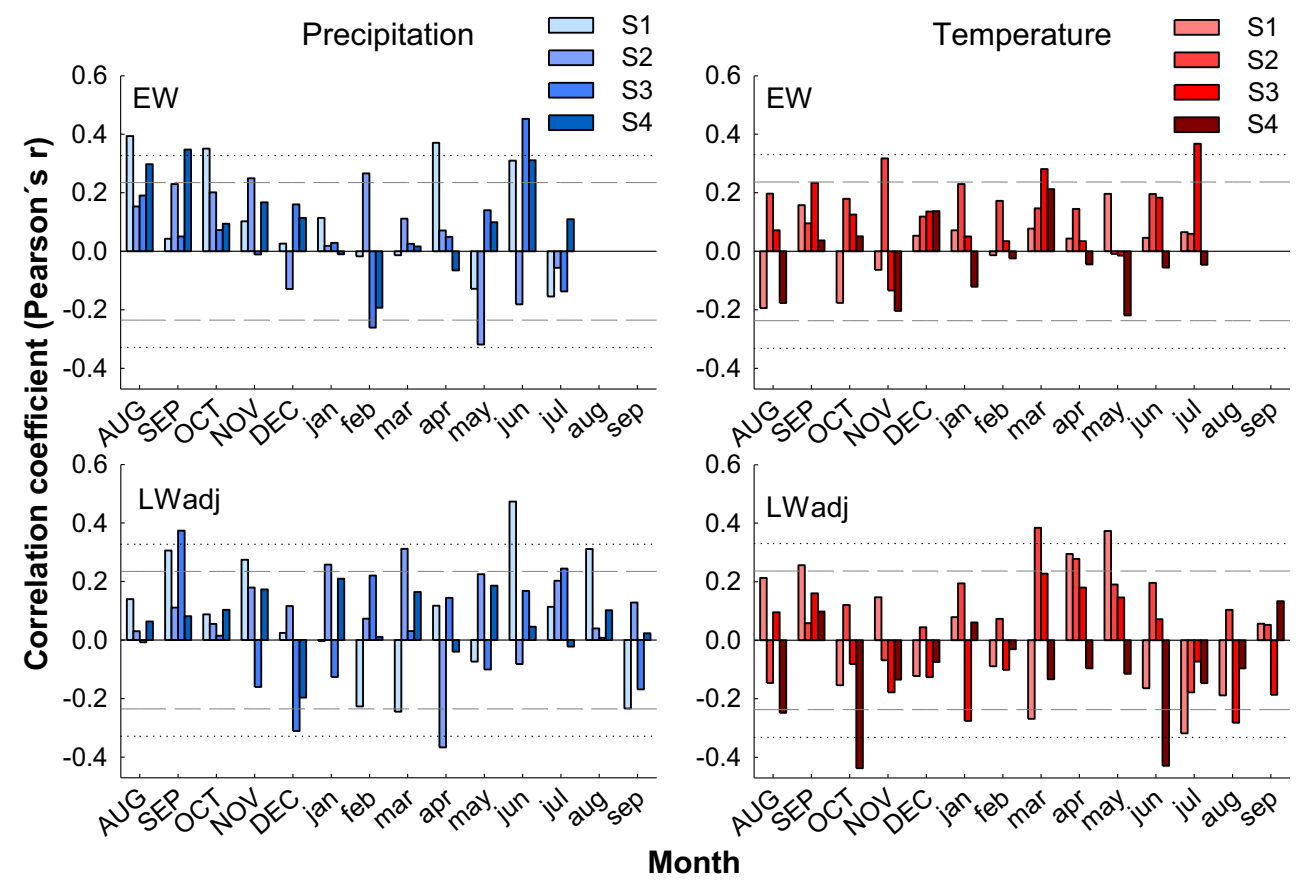


Fig. 5 Correlations (Pearson's coefficient) between earlywood (EW) and latewood adjusted $\left(\mathrm{LW}_{\mathrm{adj}}\right)$ chronologies of Pinus sylvestris with total precipitation and minimum temperature for the period 1966-2015. Correlations were calculated from August of the previous year (uppercase letters) to September of the current growth year (lowercase letters). Dashed lines indicated $P<0.05$, and dotted lines indicate $P<0.01$. Bar colors indicate the four sampled sites
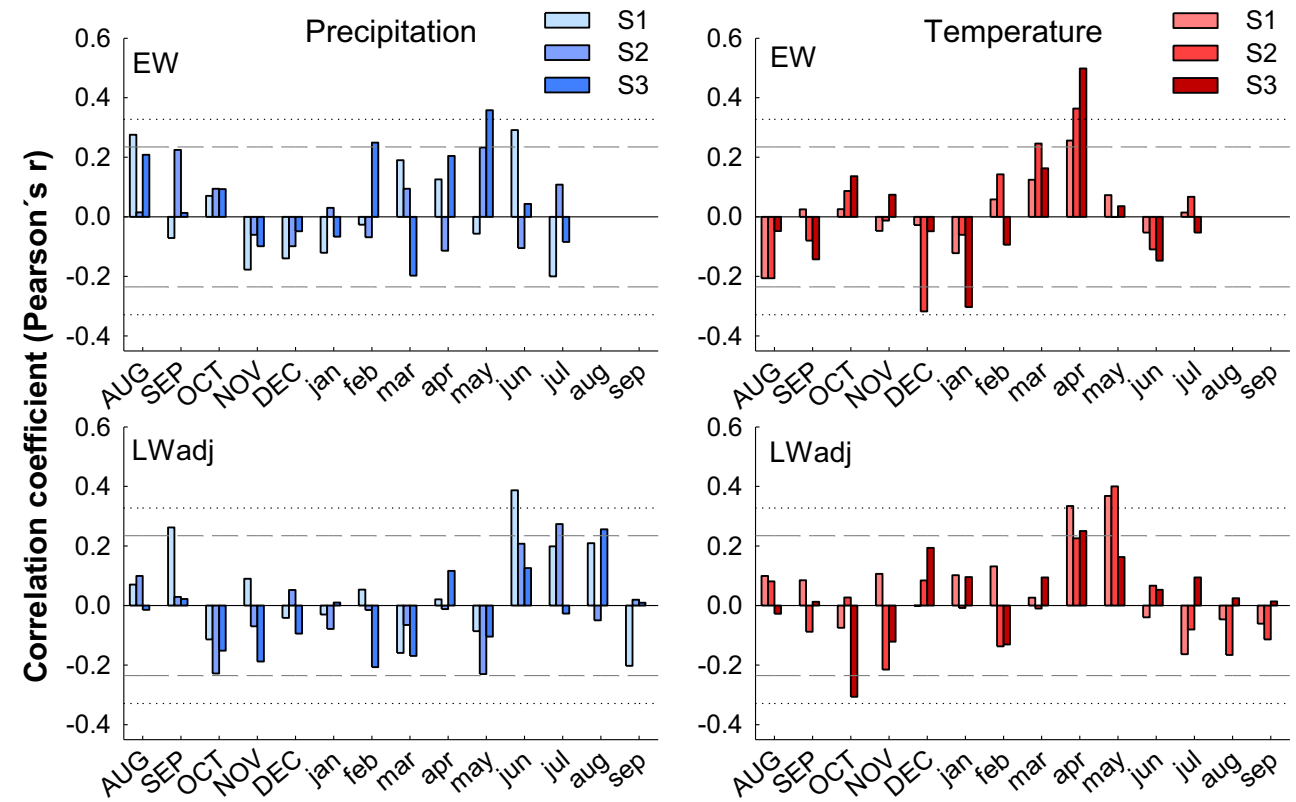

Month permafrost thawing (Vaganov et al. 1999; Bryukhanova et al. 2013). This effect was noticeable in pines, which showed greater earlywood growth under warm MarchApril conditions and more latewood growth when it was warm in April-May. Therefore, the observed warming in recent decades may have promoted an earlier permafrost thawing, triggering an earlier onset of growth and lengthening the total growing season (Nikolaev et al. 2011), resulting in higher growth rates and supporting the higher growth showed by the GAMM over time, after age effect being removed.

Temperature was not the only factor determining tree growth in the Yakutia territory. Precipitation showed high correlations with growth: pines responded to late spring
Table 3 Correlation coefficients between residual chronologies and monthly standardized precipitation-evaporation index (SPEI) at different temporal scales for the period 1966-2015.

Correlations were calculated from September of previous year to August of the current year. Values indicate maximum and minimum correlation indicating the month with highest signal (previous year in capital letters) and time lag in months (m)

\begin{tabular}{|c|c|c|c|c|c|c|c|c|c|c|}
\hline & \multirow[b]{2}{*}{ Site } & \multicolumn{3}{|l|}{ RW } & \multicolumn{3}{|l|}{ EW } & \multicolumn{3}{|l|}{$\mathrm{LW}_{\mathrm{adj}}$} \\
\hline & & $\mathrm{r}$ & month & lag & $\mathrm{r}$ & month & lag & $\mathrm{r}$ & month & lag \\
\hline \multirow[t]{8}{*}{ Larch } & \multirow[t]{2}{*}{ S1 } & -0.20 & DEC & 4 & -0.25 & Mar & 2 & -0.32 & Mar & 1 \\
\hline & & 0.47 & Jun & 15 & 0.53 & Jun & 11 & 0.54 & Jun & 1 \\
\hline & \multirow[t]{2}{*}{ S2 } & -0.23 & May & 2 & -0.27 & SEP & 5 & $-\underline{0.35}$ & Apr & 1 \\
\hline & & 0.53 & Jan & 18 & 0.48 & Feb & 1 & $\underline{0.40}$ & Mar & 10 \\
\hline & \multirow[t]{2}{*}{ S3 } & -0.27 & Feb & 1 & -0.25 & Feb & 1 & -0.27 & Jan & 2 \\
\hline & & $\underline{0.42}$ & Jun & 1 & $\underline{0.39}$ & Jun & 2 & $\underline{0.35}$ & Jul & 11 \\
\hline & \multirow[t]{2}{*}{ S4 } & -0.21 & Aug & 1 & -0.25 & SEP & 2 & -0.23 & DEC & 2 \\
\hline & & 0.51 & Jun & 11 & 0.48 & Jun & 12 & 0.33 & May & 10 \\
\hline \multirow[t]{6}{*}{ Pine } & \multirow[t]{2}{*}{ S1 } & -0.25 & DEC & 6 & -0.29 & Jul & 1 & -0.20 & May & 4 \\
\hline & & $\underline{0.39}$ & Jun & 18 & $\underline{0.38}$ & Jun & 15 & $\underline{0.35}$ & Jan & 2 \\
\hline & \multirow[t]{2}{*}{ S2 } & -0.12 & Apr & 1 & -0.12 & OCT & 4 & -0.33 & May & 8 \\
\hline & & 0.32 & Jun & 12 & 0.30 & May & 11 & 0.33 & Jul & 1 \\
\hline & \multirow[t]{2}{*}{$\mathrm{S} 3$} & -0.21 & Aug & 2 & -0.25 & SEP & 3 & -0.29 & Mar & 6 \\
\hline & & 0.30 & $\mathrm{OCT}$ & 1 & 0.33 & May & 8 & 0.18 & OCT & 1 \\
\hline
\end{tabular}

Coefficients in bold type are significant at $P<0.001$, coefficients underlined are significant at $P<0.01$, and italic coefficients are significant at $P<0.05$ 
rainfall, with later timing of signals in cooler sites. Larch also showed strong correlations with precipitation but without a clear pattern in the climate signal. This lack of a common signal may reflect the effect of local factors, such as topography on water availability, and may explain the lack of regional synchrony for this species. However, the use of SPEI revealed a common effect of spring water availability on ring width. This result was reinforced by pointer year analysis. Wide rings occurred in years with earlier precipitation events (May-June) in six out of seven sites. The seasonal thaw layer is a critical factor for water availability (Lopez et al. 2007), and any extra water supply from precipitation at the beginning of the growing season may enhance tree growth. In addition, liquid water from precipitation may also induce a deeper active soil layer as a result of heat transfer, and thus increase the nutrients available for tree growth. This result is in agreement with a previous experimental study, which showed that irrigation conducted in the permafrost area increased tree transpiration rates at the beginning of treatment, but this effect decreased later on when rainfall supplied the forest demand (Lopez et al. 2010). Thus, the association of earlier precipitation events with wide rings may be a consequence of the positive effect of extra water availability. We observed the same pattern in both species, meaning that although larch trees are better adapted to grow in the continuous permafrost zone, its radial growth may also respond to the earlier availability of liquid water. On the other hand, narrow rings occurred in years with later precipitation events (July), when the growing season would have been reduced in length before temperature again became the limiting factor (Yang et al. 2017).

The removal of the EW effect on LW reinforced the climatic signal in the last part of the ring, enhancing the latewood climate signal (Arzac et al. 2018b). Temperature had a positive effect on $\mathrm{LW}_{\text {adj }}$ in agreement with the high correlations found between maximum latewood density and summer temperature in higher latitudes (Briffa et al. 1998; Vaganov et al. 1999; Kirdyanov et al. 2008). Interestingly, precipitation also showed correlations with growth: pines responded to late spring rainfall, with later timing of the signals in cooler sites, and a month delay in the signal from EW to $\mathrm{LW}_{\mathrm{adj}}$. Again, the responses in larch were strong but showed idiosyncratic results for each site. Overall, these results indicate that water availability during summer may also limit growth at the end of the growing season in these cool environments.

Ongoing climate change will significantly impact the continuous permafrost zone in northern regions (Groisman et al. 2017). Warming is inducing an accelerated permafrost thawing (Groisman et al. 2013; Romanovsky et al. 2017), affecting water and carbon cycles (Groisman et al. 2017) as well as vegetation distribution (Tchebakova et al. 2006). Our results found significant growth increases in both species, despite previous growth projections in Yakutia territory predicting that an increase in P. sylvestris would be to the detriment of $L$. cajanderi distribution, due to the increase in the active soil layer depth which will negatively impact the growth of the better adapted to permafrost $L$. cajanderi (Tchebakova et al. 2006). Future projections should take water availability into account; although during warm and dry periods the permafrost may provide an extra water source for tree growth (Sugimoto et al. 2002; Saurer et al. 2016), if warming trends are persistent over time, melting of permafrost and increases in evapotranspiration may worsen the water balance during the growing season, potentially constraining radial growth (Groisman et al. 2013).

\section{Conclusions}

The study of environmental factors controlling tree growth and the formation of earlywood and latewood in conifers growing on permafrost in Central Yakutia revealed increased growth across sites in two species with different life strategies (i.e., evergreen and deciduous). The temperature was a critical growth factor in both conifers, but water availability also affected the radial growth. The formation of wide rings was triggered by earlier precipitation events in the two, highlighting the importance of soil water availability to the onset of the growing season at northern latitudes.

Acknowledgments We want to thank A.V. Kirdyanov and E.A. Vaganov for numerous helpful discussions and suggestions and to the editors and anonymous reviewers for their comments and suggestions, which significantly improved the manuscript. We thank David Brown for the English language edition.

Funding information This work was supported by the Russian Science Foundation (Grant 14-14-00219P, data collection) and the Ministry of Science and Higher Education of the Russian Federation "Science of Future" (Project 5.3508.2017/4.6, data measurements). A. Arzac was supported by the Russian Science Foundation (Grant 18-74-10048, data analysis and manuscript preparation). M. Popkova was supported by the Russian Foundation for Basic Research (Grant 18-34-00530).

Data availability The datasets generated and/or analyzed during the current study are available in the Harvard Dataverse repository (Arzac et al. 2019) at https://doi.org/10.7910/DVN/BWIFOX

\section{Compliance with ethical standards}

Conflicts of interest The authors declare that they have no conflict of interest. 


\section{Annexes}

Table 4 Mean tree-ring, earlywood, and latewood width for measured Larix cajanderi and Pinus sylvestris trees, and summary of dendrochronological statistics for residual chronologies for each site and parameter. The statistics shown correspond to the common period 1966-2015 in

which climate analyses were performed

Table 5 Inter-site correlation (Pearson's r) between Larix cajanderi and Pinus sylvestris RW chronologies.

\begin{tabular}{|c|c|c|c|c|c|c|c|}
\hline & Parameters & Site & Mean $\pm \mathrm{SD}(\mathrm{mm})$ & $m_{\mathrm{sx}}$ & $r_{\mathrm{bt}}$ & EPS & $\mathrm{AC} 1$ \\
\hline \multirow[t]{12}{*}{ Larix cajanderi } & \multirow[t]{4}{*}{ RW } & $\mathrm{S} 1$ & $0.57 \pm 0.20$ & 0.19 & 0.401 & 0.915 & 0.009 \\
\hline & & $\mathrm{S} 2$ & $0.73 \pm 0.19$ & 0.19 & 0.333 & 0.889 & 0.004 \\
\hline & & S3 & $0.79 \pm 0.27$ & 0.17 & 0.431 & 0.914 & 0.144 \\
\hline & & S4 & $1.11 \pm 0.53$ & 0.21 & 0.325 & 0.891 & 0.099 \\
\hline & \multirow[t]{4}{*}{ EW } & $\mathrm{S} 1$ & $0.31 \pm 0.13$ & 0.19 & 0.374 & 0.905 & 0.027 \\
\hline & & $\mathrm{S} 2$ & $0.45 \pm 0.09$ & 0.18 & 0.280 & 0.862 & -0.017 \\
\hline & & $\mathrm{S} 3$ & $0.41 \pm 0.16$ & 0.19 & 0.432 & 0.914 & -0.385 \\
\hline & & $\mathrm{S} 4$ & $0.74 \pm 0.38$ & 0.22 & 0.314 & 0.886 & 0.117 \\
\hline & \multirow[t]{4}{*}{ LW } & $\mathrm{S} 1$ & $0.26 \pm 0.09$ & 0.24 & 0.396 & 0.913 & -0.272 \\
\hline & & $\mathrm{S} 2$ & $0.27 \pm 0.11$ & 0.27 & 0.315 & 0.880 & 0.099 \\
\hline & & S3 & $0.32 \pm 0.17$ & 0.19 & 0.324 & 0.871 & -0.009 \\
\hline & & S4 & $0.36 \pm 0.17$ & 0.24 & 0.281 & 0.869 & 0.069 \\
\hline \multirow[t]{9}{*}{ Pinus sylvestris } & \multirow[t]{3}{*}{ RW } & $\mathrm{S} 1$ & $0.56 \pm 0.22$ & 0.16 & 0.405 & 0.935 & 0.147 \\
\hline & & $\mathrm{S} 2$ & $1.29 \pm 0.74$ & 0.13 & 0.385 & 0.904 & 0.046 \\
\hline & & S3 & $0.97 \pm 0.50$ & 0.09 & 0.179 & 0.739 & -0.472 \\
\hline & \multirow[t]{3}{*}{ EW } & $\mathrm{S} 1$ & $0.43 \pm 0.18$ & 0.17 & 0.359 & 0.922 & 0.172 \\
\hline & & $\mathrm{S} 2$ & $0.96 \pm 0.54$ & 0.17 & 0.348 & 0.889 & 0.034 \\
\hline & & $\mathrm{S} 3$ & $0.76 \pm 0.39$ & 0.17 & 0.170 & 0.727 & 0.076 \\
\hline & \multirow[t]{3}{*}{ LW } & $\mathrm{S} 1$ & $0.12 \pm 0.05$ & 0.16 & 0.260 & 0.881 & 0.084 \\
\hline & & $\mathrm{S} 2$ & $0.33 \pm 0.23$ & 0.17 & 0.286 & 0.857 & 0.049 \\
\hline & & S3 & $0.20 \pm 0.11$ & 0.16 & 0.204 & 0.769 & -0.028 \\
\hline
\end{tabular}

$m_{\mathrm{sx}}$, mean sensitivity; $r_{\mathrm{bt}}$, mean correlation between plants; EPS, expressed population signal; AC1, first-order autocorrelation

\begin{tabular}{lllll}
\hline & & S2 & S3 & S4 \\
\hline Larix cajanderi & S1 & 0.10 & 0.20 & -0.04 \\
& S2 & & 0 & -0.11 \\
Pinus sylvestris & S3 & & & 0.07 \\
& S1 & $\mathbf{0 . 4}$ & $\mathbf{0 . 3 4}$ & - \\
& S2 & & $\mathbf{0 . 4 8}$ & - \\
\hline
\end{tabular}

Coefficients in bold type are significant at $P<0.001$, and italic coefficients are significant at $P<0.05$

Table 6 Inter-species correlations (Pearson's $r$ ) between Larix cajanderi and Pinus sylvestris RW chronologies by species

\begin{tabular}{cccccc}
\hline \multicolumn{5}{c}{ Larix cajanderi sites } \\
& & S1 & S2 & S3 & S4 \\
Pinus sylvestris sites & S1 & $\mathbf{0 . 5 6}$ & -0.08 & 0.01 & -0.04 \\
& S2 & $\underline{0.25}$ & 0.11 & -0.03 & 0.13 \\
& S3 & 0.17 & 0.00 & -0.05 & 0.03 \\
\hline
\end{tabular}

Coefficients in bold type are significant at $P<0.001$, coefficients underlined are significant at $P<0.01$, and italic coefficients are significant at $P<0.05$ 

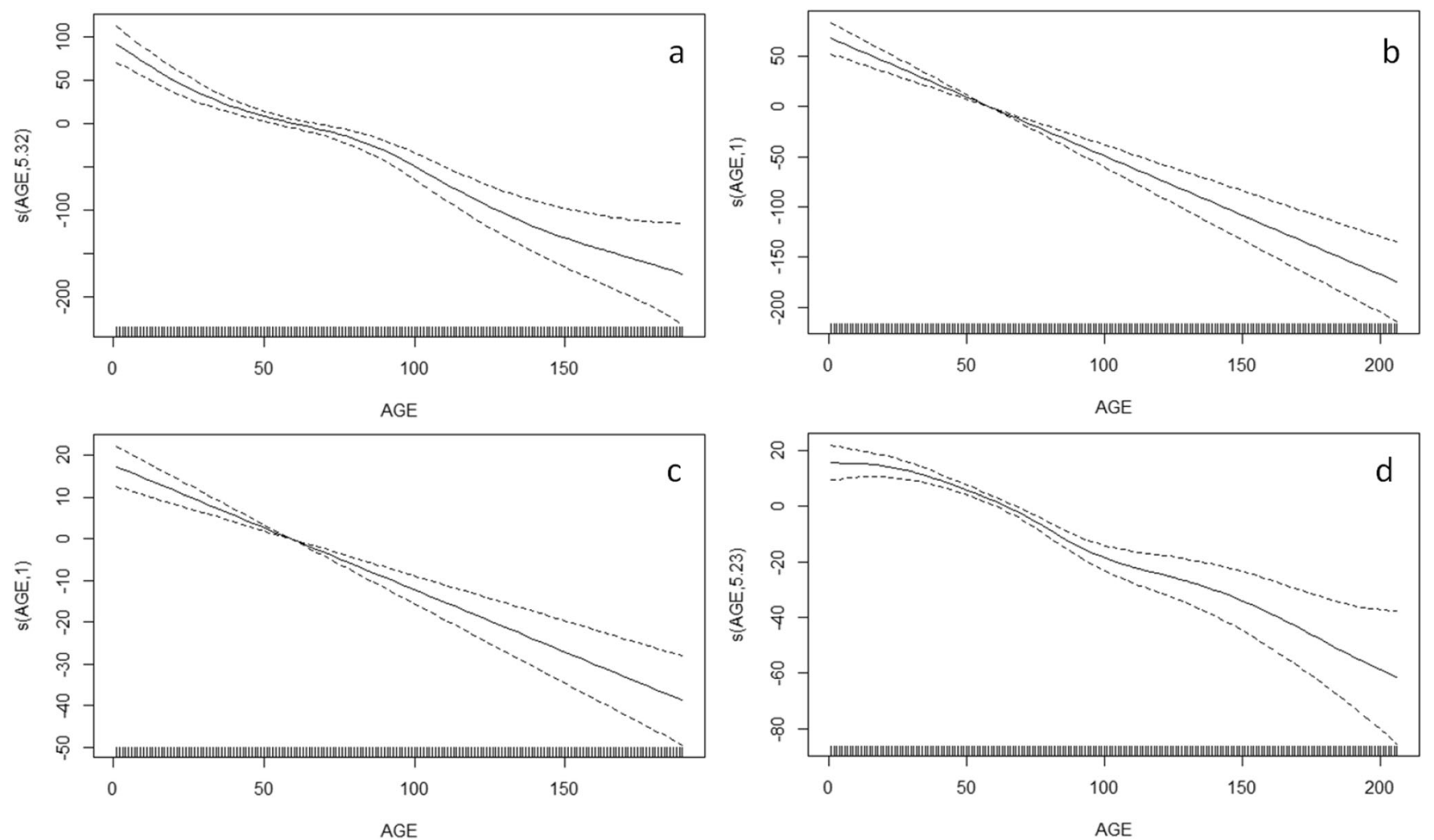

Fig. 6 Effect of tree age modeled by the GAMM on tree tree-ring width ( $\mathrm{a}$ and b, pine and larch respectively) and latewood width (c and d, pine and larch respectively). 


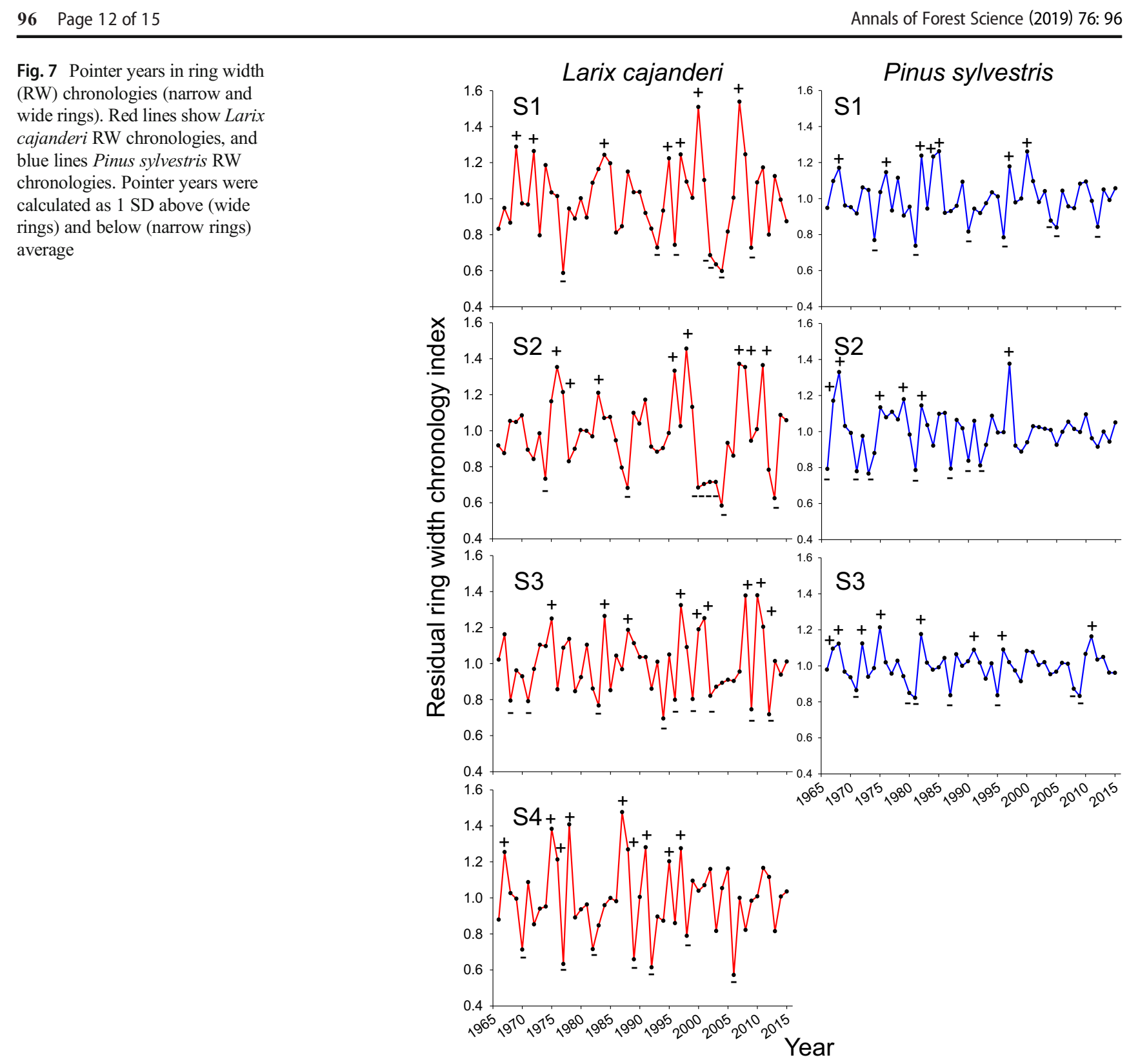

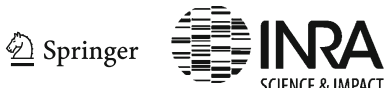




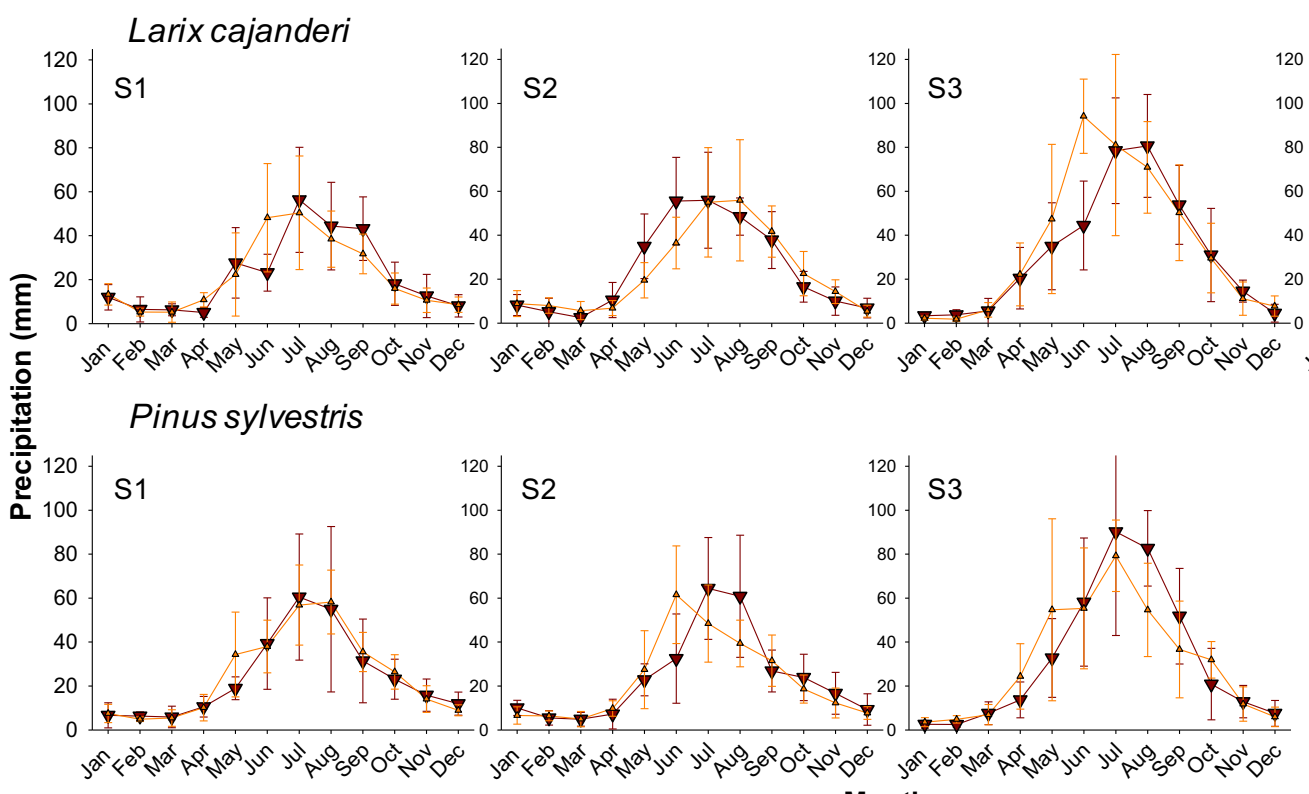

Month

Fig. 8 Effect of precipitation on the formation of pointer years. Lines with upward-pointing triangles and downward-pointing triangles indicate wide and narrow rings, respectively

\section{References}

Abaimov A (2010) Geographical distribution and genetics of Siberian larch species. In: Osawa A, Zyryanova O, Matsuura Y et al (eds) Permafrost ecosystems Siberian larch forest. Springer, Dordrecht, pp $41-55$

Antonova GF, Stasova VV (1993) Effects of environmental factors on wood formation in Scots pine stems. Trees 7:214-219. https://doi. org/10.1007/BF00202076

Antonova GF, Stasova VV (1997) Effects of environmental factors on wood formation in larch (Larix sibirica Ldb.) stems. Trees 11:462 468. https://doi.org/10.1007/s004680050108

Arzac A, Babushkina EA, Fonti P, Slobodchikova V, Sviderskaya IV, Vaganov EA (2018a) Evidences of wider latewood in Pinus sylvestris from a forest-steppe of southern Siberia. Dendrochronologia 49:1-8. https://doi.org/10.1016/j.dendro.2018. 02.007

Arzac A, Rozas V, Rozenberg P, Olano JM (2018b) Water availability controls Pinus pinaster xylem growth and density: a multi-proxy approach along its environmental range. Agric For Meteorol 250 25:171-180. https://doi.org/10.1016/j.agrformet.2017.12.257

Arzac A, Popkova M, Anarbekova A, Olano JM, Gutiérrez E, Nikolaev A, Shishov V (2019) Increasing radial and latewood growth rates of Larix cajanderi Mayr. and Pinus sylvestris L. in the continuous permafrost zone in Central Yakutia (Russia). V1. Harvard Dataverse. [Dataset]. https://doi.org/10.7910/DVN/BWIFOX

Babst F, Wright WE, Szejner P, Wells L, Belmecheri S, Monson RK (2016) Blue intensity parameters derived from Ponderosa pine tree rings characterize intra-annual density fluctuations and reveal seasonally divergent water limitations. Trees 30:1403-1415. https://doi. org/10.1007/s00468-016-1377-6

Babushkina EA, Belokopytova LV, Kostyakova TV, Kokova VI (2018) Earlywood and latewood features of Pinus sylvestris in semiarid natural zones of South Siberia. Russ J Ecol 49:209-217. https:// doi.org/10.1134/S1067413618030013

Baltzer J, Veness T, Chasmer LE, Sniderhan AE, Quinton WL (2014) Forests on thawing permafrost: fragmentation, edge effects, and net forest loss. Glob Chang Biol 20:824-834. https://doi.org/10.1111/ gcb. 12349

Björklund J, Seftigen K, Schweingruber F, Fonti P, von Arx G, Bryukhanova MV, Cuny HE, Carrer M, Castagneri D, Frank DC (2017) Cell size and wall dimensions drive distinct variability of earlywood and latewood density in Northern Hemisphere conifers. New Phytol 216:728-740. https://doi.org/10.1111/nph.14639

Bosikov NP (1998) Wetness variability and dynamics of thermokarst processes. Proceedings of the Seventh International Conference on Permafrost. pp 71-74

Briffa KR, Schweingruber FH, Jones pD, Osborn TJ, Shiyatov SG, Vaganov EA (1998) Reduced sensitivity of recent tree-growth to temperature at high northern latitudes. Nature 391:678-682. https://doi.org/10.1038/35596

Briffa KR, Shishov VV, Melvin TM, Vaganov EA, Grudd H, Hantemirov RM, Eronen M, Naurzbaev MM (2008) Trends in recent temperature and radial tree growth spanning 2000 years across Northwest Eurasia. Philos Trans R Soc Lond Ser B Biol Sci 363:2271-2284. https://doi.org/10.1098/rstb.2007.2199

Bryukhanova MV, Kirdyanov AV, Prokushkin AS, Silkin PP (2013) Specific features of xylogenesis in Dahurian larch, Larix gmelinii (Rupr.) Rupr., growing on permafrost soils in Middle Siberia. Russ J Ecol 44:361-366. https://doi.org/10.1134/S1067413613050044

Carpino OA, Berg AA, Quinton WL, Adams JR (2018) Climate change and permafrost thaw-induced boreal forest loss in northwestern Canada. Environ Res Lett 3:084018. https://doi.org/10.1088/17489326/aad74e

Cook ER, Holmes R (1996) Guide for computer program ARSTAN. In: Grissino-Mayer HD, Holmes RL, Fritts HC (eds) The international tree-ring data bank program library version 2.0 user's manual. Laboratory of Tree-Ring Research, University of Arizona, Tucson, pp 75-87

Cook ER, Peters K (1981) The smoothing spline: a new approach to standardizing forest interior tree-ring width series for dendroclimatic studies. Tree-Ring Bull 41:45-53

Domec J-C, Gartner BL (2002) How do water transport and water storage differ in coniferous earlywood and latewood? J Exp Bot 53:2369 2379. https://doi.org/10.1093/jxb/erf100 
Duchkov A (2006) Characteristics of permafrost in Siberia. In: Lombardi $\mathrm{S}$, Altunina L, Beaubien S (eds) Advances in the geological storage of carbon dioxide. Springer, pp 81-91

Falkowski P, Scholes R, Boyle E, Canadell J, Candield D, Elser J, Gruber N, Hibbard K, Hogberg P, Linder S, Mackenzie FP, Moore III, Pedersen T, Rosenthal Y, Seitzinger Y, Smetacek V, Steffen W (2010) The global carbon cycle: a test of our knowledge of earth as a system. Science 290:291-296. https://doi.org/10.1126/science. 290.5490 .291

Fedorov A, Konstantinov P (2003) Observations of surface dynamics with thermokarst initiation, Yukechi site, Central Yakutia. In: Phillips M, Springman S, Arenson L (eds) Proceedings of the Eight International Conference on Permafrost, pp 239-243

Fonti P, Von Arx G, García-González I, Eilmann B, Sass-Klassen U, Gärtner H, Eckstein D (2010) Studying global change through investigation of the plastic responses of xylem anatomy in tree rings. New Phytol 185:42-45. https://doi.org/10.1111/j.1469-8137.2009. 03030.x

Gartenr BL (1995) Patterns of xylem variation within a tree and their hydraulic and mechanical consequences. In: Gartner BL (ed) Plant stems: physiological and functional morphology. Academic Press, New York, pp 125-149

Gorokhov AN, Fedorov AN (2018) Current trends in climate change in Yakutia. Geogr Nat Resour 39:153-161. https://doi.org/10.1134/ S1875372818020087

Grissino-Mayer HD (2001) Evaluating crossdating accuracy: a manual and tutorial for the computer program COFECHA. Tree-Ring Res 57:205-221

Groisman P, Blyakharchuk TA, Chernokulsky AV, Arzhanov MM, Marchesini LB, Bogdanova E, Borzenkova II, Bulygina ON, Karpenko AA, Karpenko LV, Knight RW, Khon VC, Korovin GN, Meshcherskaya AV, Mokhov II, Parfenova EI, Razuvaev VN, Speranskaya NA, Tchebakova NM, Vygodskaya NN (2013) Climate changes in Siberia. In: Groisman P, Gutman G (eds) Regional environmental changes in Siberia and their global consequences. Springer Environmental Science and Engineering. Springer, Dordrecht, pp 57-109

Groisman P, Shugart H, Kicklighter D, Henebry G, Tchebakova N, Maksyutov S, Monier E, Gutman G, Gulev S, Qi J, Prishchepov A, Kukavskaya E, Porfiriev B, Shiklomanov A, Loboda T, Shiklomanov N, Nghiem S, Bergen K, Albrechtová J, Chen J, Shahgedanova M, Shvidenko A, Speranskaya N, Soja A, de Beurs K, Bulygina O, McCarty J, Zhuang Q, Zolina O (2017) Northern Eurasia Future Initiative (NEFI): facing the challenges and pathways of global change in the twenty-first century. Prog Earth Planet Sc 4: 41. https://doi.org/10.1186/s40645-017-0154-5

Gyllenstrand N, Ckapham D, Källman T, Lagercrantz U (2007) A Norway spruce flowering locus $\mathrm{T}$ homolog is implicated in control of growth rhythm in conifers. Plant Physiol 144:248-257. https:// doi.org/10.1104/pp.107.095802

Hacke UG, Sperry JJS, Pockman WTW, Davis SD, McCulloh HA (2001) Trends in wood density and structure are linked to prevention of xylem implosion by negative pressure. Oecologia 126:457-461. https://doi.org/10.1007/s004420100628

Helbig M, Pappas C, Sonnentag O (2016) Permafrost thaw and wildfire: equally important drivers of boreal tree cover changes in the Taiga Plains, Canada. Geophis Res Lett 43:1598-1606. https://doi.org/10. 1002/2015GL067193

Hellmann L, Agafonov L, Charpentier Ljungqvist F, Churakova (Sidorova) O, Düthorn E, Esper J, Hülsmann L, Kirdyanov AV, Moiseev P, Myglan VS, Nikolaev AN, Reinig F, Schweingruber FH, Solomina O, Tegel W, Büntgen U (2016) Diverse growth trends and climate responses across Eurasia's boreal forest. Environ Res Lett 11:074021. https://doi.org/10.1088/1748-9326/11/7/074021

IPCC (2014) Climate change 2014: synthesis report. Contribution of Working Groups I, II and III to the Fifth Assessment Report of the
Intergovernmental Panel on Climate Change. IPCC, Geneva, Switzerland

Jorgenson MT, Osterkamp TE (2005) Response of boreal ecosystems to varying modes of permafrost degradation. Can J For Res 35:2100 2111. https://doi.org/10.1139/x05-153

Kirdyanov AV, Treydte KS, Nikolaec A, Helle G, Schleser GH (2008) Climate signals in tree-ring width, density and $\delta^{13} \mathrm{C}$ from larches in Eastern Siberia (Russia). Chem Geol 252:31-41. https://doi.org/10. 1016/j.chemgeo.2008.01.023

Lopez MLC, Saito H, Kobayashi Y, Shirota T, Iwahana G, Maximov TC, Fukuda M (2007) Interannual environmental-soil thawing rate variation and its control on transpiration from Larix cajanderi, Central Yakutia, Eastern Siberia. 251-260. doi: https://doi.org/10.1016/j. jhydrol.2007.02.039

Lopez MLC, Gerasimov E, Machimura T, Takakai F, Iwahana G, Fedorov AN, Fukuda M (2008) Comparison of carbon and water vapor exchange of forest and grassland in permafrost regions, Central Yakutia, Russia. J Hydrol 148:1968-1977. https://doi.org/ 10.1016/j.agrformet.2008.09.013

Lopez MLC, Shirota T, Iwahana G, Koide T, Maximov TC, Fukuda M, Saito H (2010) Effect of increased rainfall on water dynamics of larch (Larix cajanderi) forest in permafrost regions, Russia: an irrigation experiment. J For Res 15:365-373. https://doi.org/10.1007/ s10310-010-0196-7

Meko DM, Baisan CH (2001) Pilot study of latewood-width of conifers as an indicator of variability of summer rainfall in the North American monsoon region. Int J Climatol 21:697-708. https://doi. org/10.1002/joc.646

Melnikov V, Drozdov D (2006) Distribution of permafrost in Russia. In: Lombardi S, Altunina L, Beaubien S (eds) Advances in the geological storage of carbon dioxide. Springer, pp 69-80

Nikolaev AN (2003) The influence of soil temperature on radial increments of larch and pine stems in Central Yakutia. Proceedings of the Eight International Conference on Permafrost. pp. 811-814

Nikolaev AN, Fedorov PP, Desyatkin AR (2009) Influence of climate and soil hydrothermal regime on radial growth of Larix cajanderi and Pinus sylvestris in central Yakutia, Russia. Scand J For Res 24:217226. https://doi.org/10.1080/02827580902971181

Nikolaev AN, Fedorov PP, Desyatkin AR (2011) Effect of hydrothermal conditions of permafrost soil on radial growth of larch and pine in Central Yakutia. Contemp Probl Ecol 4:140-149. https://doi.org/10. 1134/S1995425511020044

Olano JM, Eugenio M, García-Cervigón AI, Folch M, Rozas V (2012) Quantitative tracheid anatomy reveals a complex environmental control of wood structure in continental Mediterranean climate. Int J Plant Sci 173:137-149. https://doi.org/10.1086/663165

Olano JM, Linares JC, García-Cervigón AI, Arzac A, Delgado A, Rozas V (2014) Drought-induced increase in water-use efficiency reduces secondary tree growth and tracheid wall thickness in a Mediterranean conifer. Oecologia 176:273-283. https://doi.org/10. 1007/s00442-014-2989-4

Popkova MI, Vaganov EA, Shishov VV, Babushkina EA, Rossi S, Fonti MV, Fonti P (2018) Modeled tracheidograms disclose drought influence on Pinus sylvestris tree-rings structure from Siberian foreststeppe. Front Plant Sci 9:1144. https://doi.org/10.3389/fpls.2018. 01144

R Core Team (2016) R: a language and environment for statistical computing. R Foundation for Statistical Computing, Vienna URL. https://www.R-project.org/

Romanovsky VE, Smith SL, Shiklomanov NI, Streletskiy DA, Isaksen K, Kholodov AL, Christiansen HH, Drozdov DS, Malkova GV, Marchenko SS (2017) Terrestrial permafrost. Bull Am Meteorol Soc 98:147-149

Rossi S, Deslauriers A, Gričar J, Seo J-W, Rathgeber C, Andofillo T, Morin H, Levanic T, Oven P, Jalkanen R (2008) Critical temperatures for xylogenesis in conifers of cold climates. Glob Ecol 
Biogeogr 17:696-707. https://doi.org/10.1111/j.1466-8238.2008. 00417.x

Rossi S, Anfodillo T, Cufar K, Cuny HE, Fonti P, Frank D, Gričar J, King GM, Krause G, Morin H, Oberhuber W, Prislan P, Rathgeber C (2013) A meta-analysis of cambium phenology and growth: linear and non-linear patterns in conifers of the northern hemisphere. Ann Bot 112:1911-1920. https://doi.org/10.1093/aob/mct243

Saurer M, Kirdyanov AV, Prokushkin AS, Rinne KT, Siegwolf RT (2016) The impact of an inverse climate-isotope relationship in soil water on the oxygen-isotope composition of Larix gmelinii in Siberia. New Phytol 209:955-9645. https://doi.org/10.1111/nph.13759

Schlesinger WH, Jasechko (2014) Transpiration in the global water cycle. Agric For Meteorol 189-190:115-117. https://doi.org/10.1016/j. agrformet.2014.01.011

Shi J, Liu Y, Vaganov EA, Jinbao L, Cai Q (2008) Statistical and processbased modeling analyses of tree growth response to climate in semiarid area of north central China: a case study of Pinus tabulaeformis. J Geophys Res Biogeosci 113:G01026. https://doi.org/10.1029/ 2007JG000547

Sperry JS, Hacke UE, Pittermann J (2006) Size and function in conifer tracheids and angiosperm vessels. Am J Bot 93:1490-1500. https:// doi.org/10.3732/ajb.93.10.1490

Stahle DW, Cleaveland MK, Grissino-Mayer HD, Grissin RD, Fk F, Therrell MD, Burnette DJ, Meko D, Villanueva Diaz J (2009) Cool- and warm-season precipitation reconstructions over western New Mexico. J Clim 22:3729-3750. https://doi.org/10.1175/ 2008JCLI2752.1

Sugimoto A, Yanagisawa N, Naito D, Fujita N, Maximov TC (2002) Importance of permafrost as a source of water for plants in east Siberian taiga. Ecol Res 17:493-503. https://doi.org/10.1046/j. 1440-1703.2002.00506.x

Sugimoto A, Naito D, Yanagisawa N, Ichiyanagi K, Kurita N, Kubota J, Kotake T, Ohata T, Maximov TC, Fedorov AN (2003) Characteristics of soil moisture in permafrost observed in East Siberian taiga with stable isotopes of water. Hydrol Process 17: 1073-1092. https://doi.org/10.1002/hyp.1180

Tchebakova N, Rehfeldt G, Parfenova E (2006) Impacts of climate change on the distribution of Larix spp. and Pinus sylvestris and their climatypes in Siberia. Mitig Adapt Strateg Glob Chang 11: 861-882. https://doi.org/10.1007/s11027-005-9019-0

Tychkov I, Sviderskaya IV, Babushkina EA, Popkova MI, Vaganov EA, Shishov VV (2019) How can the parameterization of a processbased model help us understand real tree-growth. Trees 33:345357. https://doi.org/10.1007/s00468-018-1780-2

Tyree MT, Zimmermann MH, Martin H (2002) Xylem structure and the ascent of sap. Springer, Berlin. https://doi.org/10.1007/978-3-66204931-0

Vaganov EA (1990) The tracheidogram method in tree-ring analysis and its application. In: Cook E, Kairiukstis L (eds) Methods of dendrochronology. Springer, Netherlands, pp 63-76

Vaganov EA, Hughes MK, Kirdyanov AV, Schweingruber FH, Silkin PP (1999) Influence of snowfall and melt timing on tree growth in subarctic Eurasia. Nature 400:149-151. https://doi.org/10.1038/ 22087

Vaganov EA, Hughes MK, Shashkin AV (2006) Growth dynamics of conifer tree rings images of past and future environments. Springer-Verlag, Berlin.https://doi.org/10.1017/ CBO9781107415324.004

Vicente-Serrano SM, Beguería S, López-Moreno JI (2010) A multi-scalar drought index sensitive to global warming: the standardized precipitation evapotranspiration index-SPEI. J Clim 23:1696-1718. https://doi.org/10.1175/2009JCLI2909.1

Yang B, He M, Shishov VV, Tychkov I, Vaganov EA, Rossi S (2017) New perspective on spring vegetation phenology and global climate change based on Tibetan Plateau tree-ring data. PNAS 114:69666971. https://doi.org/10.1073/pnas.1616608114

Zuur AF, Ieno EN, Walker NJ, Saveliev AA, Smith GM (2009) Mixed effects models and extensions in ecology with R. Springer, New York

Zweifel R, Zimmermann L, Zeugin F, Newbery DM (2006) Intra-annual radial growth and water relations of trees: implications towards a growth mechanism. J Exp Bot 57:1145-1459. https://doi.org/10. 1093/jxb/erj125

Publisher's note Springer Nature remains neutral with regard to jurisdictional claims in published maps and institutional affiliations. 